\title{
BIOLOGICAL CHARACTERISTIC OF ELEVEN-SPOT LADYBIRD Coccinella undecimpunctata (LINNAEUS), REARED ON COWPEA APHID, Aphis craccivora (KOCK), UNDER LABORATORY CONDITIONS Iman I. Imam \\ Economic Entomology Unit, Plant Protection Department, Desert Research Center.
}

\begin{abstract}
The predatory potential and biology of Coccinella undecimpunctata L. fed on cowpea aphid, Aphis craccivora Kock have been studied under laboratory conditions $\left(25 \pm 2^{\circ} \mathrm{C}\right.$ and $60 \pm 5 \%$ R.H.). The results revealed that mean consumption of aphids per C. undecimpunctata adult was 80.8, whereas, 21.76, 55.67, 107.86 and 231.03 aphids were consumed by a single larva during $1^{\text {st }}, 2^{\text {nd }}, 3^{\text {rd }}$ and $4^{\text {th }}$ instars, respectively. A single female laid $195.0 \pm 13.10$ eggs during entire life period. The egg hatching was $96.3 \%$ while $82.0 \%$ larvae survived up to pupal stage. Total larval and pupal duration was $23.4 \pm 0.35$ and $5.3 \pm 0.56$ days, respectively. Mean percent emergence in male and female was $36.6 \pm 2.98$ and $56.6 \pm 4.21$, respectively. Male to female sex ratio was recorded 1:1.5.
\end{abstract}

\section{INTRODUCTION}

Predators are a major component of natural control and integrated pest management programs of scale insects (Coleoptera : Coccenillidae). A predator is an organism that attacks, kills, and feeds on several to many other individuals in its lifetime. Scales are often controlled by predators as beetles, bugs, lacewings and mites. Coccinella undecimpunctata $L$. is one of the common species in Egypt; it is considered as an important predator of the eggs and the newly hatched larvae of cotton leaf worm and aphids. It is characterized with black color, orange elytra spotted with 11 black spots (Dobzhansky, 1933; Ibrahim, 1955 and Brown, 1962). The race of $C$. undecimpunctata is widely distributed all over the country where it occurs all the year round,

Piercing-Sucking insects especially aphids are considered as one of the most serious pest all over the world. It has a wide host range including cucumber. Also they transmit serious plants pathogenic viruses such as cucumber mosaic virus (Gerling, 1990). Aphids are controlled by different chemical insecticides which pollute the environment. The extensive and repeated use of insecticides has disrupted the natural balance between these pests and their natural enemies (Amer and Marei, 2001). Studying the relationship between sap sucking insects pests as favorable preys and their predators enable to know how these predators cold share in this natural balance. Moreover, it could give the opportunity for determining the best timing for releasing of more effective predatory species in the fields, suffering from pests attack, in the frame of Integrated Pest Management (IPM) 
strategies, side by side with safe alternative control methods (Bahy El-Din, 2006).

The aphids, Aphis craccivora Kock (Hemiptera: Aphididae) constitute the essential prey for the majority of Coccinellidae (Saharaoui et al., 2001). C. undecimpunctata is an extremely important predator of many species aphids (Ibrahim, 1948 \& 1955b). Both the adult and larval stages of many coccinellid species feed on insects harmful to plants, such as aphids (Ibrahim, 1955a Anonymous, 1997; and Waldbauer, 1988). Therefore, the objective of the present study was aimed to investigate some biological characteristic of the coccinellid predator $C$. undecimpunctata under laboratory conditions.

\section{MATERIALS AND METHODS}

\section{Insect culture:}

A culture of $C$. undecimpunctata was reared in $1 \mathrm{~L}$ glass-Jar, five pairs / jar. Heavily aphid infested leaves were introduced to the Jar as food. The food was replaced daily. Newly laid egg masses were collected. Each eggmass was put in a new glass-Jar until hatching. After hatching the food was offered and replaced daily. Larval instars were recorded. Feeding was stopped after pupation until the emergence of new adults. Newly emerged adults were sexed and every 5 pairs were used for new generations. The culture was reared for several generations under laboratory conditions of 25 $+2^{\circ} \mathrm{C}, 60+5 \%$ R. H.

Mass rearing of Aphids was carried out in a wooden box with two sides were made up of wire netting and the upper part was made up of glass. The insects feed on bean plants (Vicia faba) by sucking plant juices. Seeds of beans were planted in rearing pots. When the plants grew above the soil (7 days), artificial infestation was achieved by transferring heavily infested leaves to the new plants. Aphids were transferred weekly from old to young plants. The colony was maintained under laboratory conditions.

Mass rearing of both prey and predator was carried out in the laboratory of the Economic Entomology Unit, Plant Protection Department, Desert Research Center.

Thirty eggs of predator were observed in six replications for percent hatching and incubation period was recorded. After hatching, the larvae were collected with a fine hair brush and placed in new glass jars. In six replications thirty larvae each were observed for larval and pupal duration (days) from which later percent pupation and mortality was calculated. Each larval instar was provided with a known number of aphids (nymphs, adults) for feeding. The numbers of aphids was increased daily and as the larvae entered to next instar. The feeding potential was recorded by counting the number of aphids, fed by $1^{\text {st }}, 2^{\text {nd }}, 3^{\text {rd }}$ and $4^{\text {th }}$ instars of $C$. undecimpunctata up to pupation. Thirty pupae per replicate were used in six replications to record the data on percent male and female emergence and sex ratio. Longevity and fecundity of predator's female on aphids were noted. 


\section{RESULTS AND DISCUSSION}

Data in (Table 1) show that eggs incubation period was $5.1 \pm 0.51$ days, percent egg hatching was $96.3 \pm 2.05 \%$ and percent mortality was observed $3.6 \pm 2.78 \% \mathrm{Xu}(1985)$ recorded incubation period (3-4 days) nearly close to that in present studies.

(Table 1): Hatching, incubation and mortality of eggs of $C$. undecimpunctata.

\begin{tabular}{|c|c|c|c|}
\hline $\begin{array}{c}\text { Eggs (number) } \\
\text { per replicate }\end{array}$ & $\begin{array}{c}\text { Incubation } \\
\text { Period (days) }\end{array}$ & Hatching (number) & $\begin{array}{c}\text { Mortality of eggs } \\
\text { (number) }\end{array}$ \\
\hline 30 & $5.1 \pm 0.51$ & $\begin{array}{c}28.9 \pm 0.38 \\
(96.3 \pm 2.05 \%)\end{array}$ & $\begin{array}{c}1.1 \pm 0.81 \\
(3.6 \pm 2.78 \%)\end{array}$ \\
\hline
\end{tabular}

Results in (Table 2) indicated that mean duration of $1^{\text {st }}, 2^{\text {nd }}, 3^{\text {rd }}$ and $4^{\text {th }}$ larval instars were $3.2 \pm 0.51,5.1 \pm 0.35,6.5 \pm 0.56$ and $8.6 \pm 0.22$ days respectively and the pupal period was $5.3 \pm 0.56$ days. Debaraj and Singh (1990) reported that the pupal stage may last from 3-12 days depending upon availability of food and temperature. Takahashi (1987) observed cannibalism in C. undecimpunctata Linn. and reported that with in adequate supply of aphids, coccinellids eggs were occasionally eaten by $1^{\text {st }}$ and ${ }^{2 n d}$ instar but never by $3^{\text {rd }}$ and $4^{\text {th }}$ instar. Mean percent pupation, and pupal mortality was, $82.0 \pm 5.60 \%$ and $18.0 \pm 5.60 \%$, respectively (Table 3 ).

(Table 2): Duration period (days) of larvae and pupa stages of $C$. undecimpunctata.

\begin{tabular}{|c|c|c|c|c|c|c|}
\hline \multicolumn{4}{|c|}{ Duration of larval instars (days) } & \multirow{2}{*}{$\begin{array}{c}\text { Total larval } \\
\begin{array}{c}\text { Period } \\
\text { (days) }\end{array}\end{array}$} & \multirow{2}{*}{$\begin{array}{l}\text { Pupal } \\
\text { Period } \\
\text { (days) }\end{array}$} & \multirow{2}{*}{$\begin{array}{c}\text { Total larval \& } \\
\text { pupal } \\
\text { duration(days) }\end{array}$} \\
\hline first & second & third & fourth & & & \\
\hline $3.2 \pm 0.5$ & $5.1 \pm 0$ & .56 & $8.6 \pm 0.22$ & $23.4 \pm 0.35$ & $5.3 \pm 0.56$ & $28.7 \pm 1.83$ \\
\hline
\end{tabular}

(Table 3): Percent pupation and mortality of $C$. undecimpunctata.

\begin{tabular}{|c|c|c|}
\hline $\begin{array}{c}\text { Larvae (number) } / \\
\text { replicate }\end{array}$ & $\begin{array}{c}\text { Pupal recovery / } \\
\text { replicate }\end{array}$ & $\begin{array}{c}\text { Pupal mortality / } \\
\text { replicate }\end{array}$ \\
\hline 30 & $24.6 \pm 1.34$ & $5.2 \pm 1.34$ \\
& $(82.0 \pm 5.60 \%)$ & $(18.0 \pm 5.60 \%)$ \\
\hline
\end{tabular}

The data represented in (Table 4) showed that, the mean male and female emergence was $36.6 \pm 2.98$ and $56.6 \pm 4.21$ percent, respectively. Mean pupal mortality was $17.7 \pm 6.2 \%$. Male to female sex ratio sex ratio was $1: 1.5 \pm 0.18$. It showed that sex ratio was skewed to female adults in the predatory beetle. As a result beetle population increased rapidly and made biocontrol of aphid more effective (Saharia, 1980).

(Table 4): Percent emergence, sex ratio and mortality of adults of $C$. undecimpunctata.

\begin{tabular}{|c|c|c|c|c|}
\hline \multirow{2}{*}{$\begin{array}{l}\text { Pupae (No) / } \\
\text { replicate }\end{array}$} & \multicolumn{2}{|c|}{ Adult emergence } & \multirow{2}{*}{\begin{tabular}{|c|} 
Total male \& \\
female mortality \\
$(\%)$
\end{tabular}} & \multirow{2}{*}{$\begin{array}{c}\text { Male to } \\
\text { female ratio }\end{array}$} \\
\hline & Males (No.) & Female (No.) & & \\
\hline 30 & $\begin{array}{c}11.0 \pm 0.89 \\
(36.6 \pm 2.98 \%)\end{array}$ & $\begin{array}{c}17.0 \pm 1.26 \\
(56.6 \pm 4.21 \%)\end{array}$ & $6.6 \pm 4.21$ & $1: 1.5 \pm 0.18$ \\
\hline
\end{tabular}


(Table 5) showed that mean percent consumption of aphids by coccinellid adults was $89.7 \pm 5.74 \%$. A single female laid $195.0 \pm 13.10$ eggs in its entire life span. Data in (Table 6) revealed that the mean consumption of aphids by coccinelids larvae of first, second, third and fourth instars were $72.55 \pm 2.25,85.65 \pm 3.25,89.88 \pm 3.03$ and $92.41 \pm 4.2$, respectively. Dixon et al. (1997) studied that the number of aphids consumed per day per larva varied from 1st to $4^{\text {th }}$ instars. Dixon (2000) and Srivastiva et al. (1987) reported that among all larval stages, $4^{\text {th }}$ instar took more days and it was difficult to provide enough aphids to satisfy their voraciousappetites. Similar observations were recorded in our experiment that fourth instar fed voraciously for many days. Singh and Singh $(1993,1994)$ reported that larvae of ladybird beetle (C. septempunctata) behaved aggressively and their feeding on aphids was voracious.

(Table 5): Feeding capacity per adult, female longevity and fecundity of C. undecimpunctata, female

\begin{tabular}{|c|c|c|c|}
\hline $\begin{array}{c}\text { Aphids offered } \\
\text { (number) }\end{array}$ & $\begin{array}{c}\text { Aphids consumed } \\
\text { (number) }\end{array}$ & $\begin{array}{c}\text { Eggs laid per } \\
\text { female (number) }\end{array}$ & $\begin{array}{c}\text { Female longevity } \\
\text { (days) }\end{array}$ \\
\hline 90 & $\begin{array}{c}80.8 \pm 6.21 \\
(89.7 \pm 5.74 \%)\end{array}$ & $195.0 \pm 13.10$ & $102.0 \pm 5.48$ \\
\hline
\end{tabular}

(Table 6): Aphid consumption by different larval instars of $C$. undecimpunctata.

\begin{tabular}{|l|c|c|c|c|}
\hline Instars & Age (days) & $\begin{array}{c}\text { Aphid offered } \\
\text { (number) }\end{array}$ & $\begin{array}{c}\text { Aphids } \\
\text { consumption } \\
\text { (number) }\end{array}$ & Consumption (\%) \\
\hline \multirow{4}{*}{ First } & 1 & 25 & 15.2 & 60.8 \\
\cline { 2 - 5 } & 2 & 30 & 21.1 & 70.33333 \\
\cline { 2 - 5 } & 3 & 35 & 29 & 82.8 \\
\cline { 2 - 5 } Second & Mean & 30 & $21.76 \pm 3.06$ & $72.55 \pm 2.25$ \\
\cline { 2 - 5 } & 4 & 50 & 39.1 & 78.2 \\
\cline { 2 - 5 } & 5 & 60 & 52.1 & 86.83 \\
\cline { 2 - 5 } & 6 & 70 & 62.3 & 89 \\
\cline { 2 - 5 } & 7 & 80 & 69.2 & 86.5 \\
\hline \multirow{4}{*}{ Third } & Mean & 65 & $55.67 \pm 2.01$ & $85.65 \pm 3.25$ \\
\cline { 2 - 5 } & 8 & 100 & 88.5 & 88.5 \\
\cline { 2 - 5 } & 9 & 110 & 97.7 & 88.81 \\
\cline { 2 - 5 } & 10 & 120 & 108.2 & 90.16 \\
\cline { 2 - 5 } & 11 & 130 & 115.8 & 89.07 \\
\cline { 2 - 5 } & 12 & 140 & 129.1 & 92.21 \\
\cline { 2 - 5 } & Mean & 120 & $107.86 \pm 1.02$ & $89.88 \pm 3.03$ \\
\cline { 2 - 5 } & 13 & 200 & 176.2 & 88.1 \\
\cline { 2 - 5 } & 14 & 220 & 205.1 & 93.22 \\
\cline { 2 - 5 } & 15 & 240 & 222 & 92.5 \\
\cline { 2 - 5 } & 16 & 260 & 245.2 & 94.30 \\
\cline { 2 - 5 } & 17 & 280 & 256.6 & 91.64 \\
\cline { 2 - 5 } & 18 & 300 & 281.1 & 93.7 \\
\hline & Mean & 250 & $231.03 \pm 3.22$ & $92.41 \pm 4.2$ \\
\hline
\end{tabular}




\section{REFERENCES}

AMER, E.M. AND. MAREI, S. S (2001): Effect of Neium oleander leaf extract on the green lacewing, Chrysoperla carnea Steoh. (Neuroptera: Chrysopidae). Egypt J. Bio. Pest Control, 11 (1): 39-44.

ANONYMOUS (1997): Ladybrid Beetle. Pp. in ed., Microsoft Encarta 97 Encyclopedia. Houghton Mifflin Company

BAHY EL-DIN, I. A. E. (2006): Studies on the biology and feeding capacity of some coccinellid species. Unpublished M.Sc. Thesis, Fac. of Agric., Moshtohor Benha Univ., Egypt.

BROWN, W.J. (1962): A Revision of the Forms of Coccinella L. Occurring in America North of Mexico (Coleoptera: Coccinellidae), Canadian Ent. 94: 785-808.

DEBARAJ, Y. AND SINGH, T. K. (1990): Biology on an aphidophagous Coccinella predator, Coccinella tranversalis. J. biol. Cont., 4: 93-95.

DIXON, A. F. G., HEMPTINNE, J AND KINDLMANN, P., (1997): Effectiveness of lady bird beetle as biological control agents, patterns and processes. Entomophaga, 42: 71-83.

DIXON, A.F.G., (2000): Insect predator-prey dynamics. Ladybird beetles and biological control. University of East Anglia. Cambridge University Press, pp. 1.

DOBZHANSKY, TH. (1933): The North American Beetles of the Genus Coccinella, Proceedings of the United States National Museum, Vol. 80, Art. 4, pp. 1-32.

GERLING, D. (1990): Natural enemies of whiteflies: predators and parasitoid. In "Whiteflies:Their bionomics, pest status and management" (D. Gerling, Ed.) pp.147-185. Intercept Andover, UK.

IBRAHIM, M.M. (1948): The morphology and anatomy of Coccinella undecimpunctata aegyptiaca Reiche. Bull. Soc. 1er Entom., XXXII: 305-316.

IBRAHIM, M.M. (1955a): Studies on Coccinella undecimpunctata aegyptiaca Reiche I. Preliminary Notes and Morphology of the Early Stages, Bull. Soc. Ent. Egypt,XXXIX, 251-274.

IBRAHIM, M.M. (1955b): Studies on Coccinella undecimpunctata aegyptiaca Reiche. II. Biology and life-history. Bull. Soc. Entom., Egypt, XXXIX: 395-423.

SAHARAOUI, L.; GOURREAU, J. M. AND PERTI, G. I. (2001): Biological parameters of some aphidophgous coccinellids in Algeria (Coleoptera: Coccinellidae). Bulletin de la Society Zoologique de France.126 (4): 351-373.

SAHARIA, D., (1980): Some aspects of the biology of coccinellid predators associated with Aphis cracivora Koch on cowpeas. J. Res. Asam Agric. Univ., 1: 82-89.

SINGH, D. AND SINGH, H., (1993): Biology of ladybird beetle Coccinella septempunctata. Ann. Biol., 9: 250-253. 
SINGH, H. S. AND SINGH, R., (1994): Life fecundity table of Coccinella septempunctata L. predating on mustard aphid (Lipaphis erysimi Kalt.) under laboratory and field conditions. J. ent. Res., 18: 297-303.

SRIVASTIVA, A.S., KATIYAR, R. R., UPADHYAY, K.D. AND SINGH, S.V., (1987): Studies on the food preference of Coccinella septempunctata $L$. (Coleoptra: Coccinellidae). Ind. J. Ent., 41: 551-552.

TAKAHASHI, K., (1987): Cannibalism by the larvae of Coccinella septempunctata Bruckii. Mulsant (Coleoptera: Coccinellidae) in mass rearing experiments. Jap. J. appl. Ent. Zool., 31: 201-205.

WALDBAUR, G. (1988): The birder's Bug Book. Havard University Press, Cambridage, Massachusetts.

XU, H.X. (1985): Vertical distribution of Coccinella undecimpunctata L. and its utilization for control of aphids. Nat. Ent. Insects, 794: 204-207.

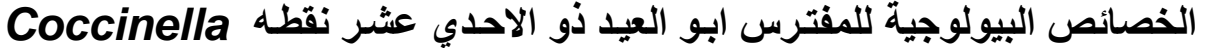 Aphis craccivora علي من البقوليات الاحير undecimpunctata إيمان ابراهيم إمام إمام

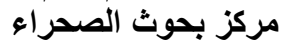

في هذا البحث نم دراسة القدره الافتراسيه للمفترس ابو العيد ذو الاحدي عشره نقطه

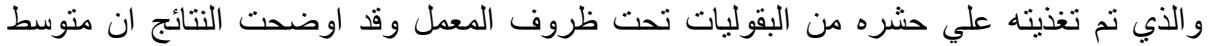

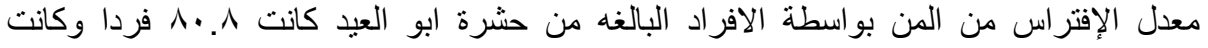

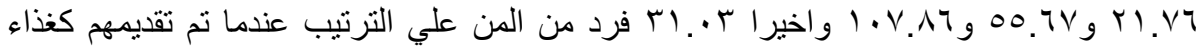

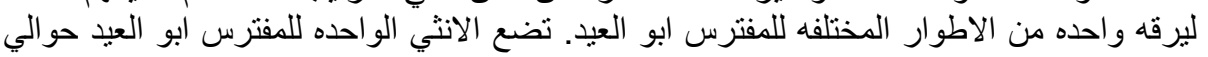

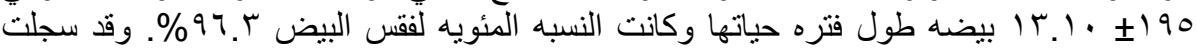

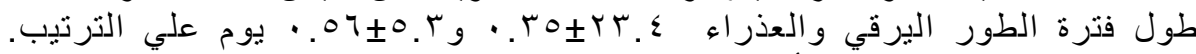

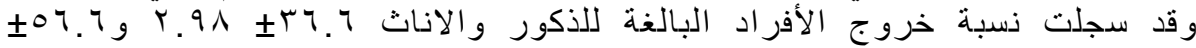

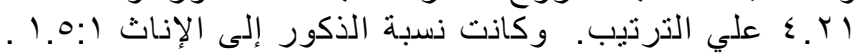

